This item was submitted to Loughborough's Research Repository by the author.

Items in Figshare are protected by copyright, with all rights reserved, unless otherwise indicated.

\title{
Festive television in the socialist world: From media events to media holidays
}

PLEASE CITE THE PUBLISHED VERSION

https://doi.org/10.1386/jptv.5.1.49_1

PUBLISHER

(c) Intellect Ltd

VERSION

AM (Accepted Manuscript)

PUBLISHER STATEMENT

This work is made available according to the conditions of the Creative Commons Attribution-NonCommercialNoDerivatives 4.0 International (CC BY-NC-ND 4.0) licence. Full details of this licence are available at: https://creativecommons.org/licenses/by-nc-nd/4.0/

\section{LICENCE}

CC BY-NC-ND 4.0

\section{REPOSITORY RECORD}

Huxtable, Simon, Sabina Mihelj, Alice Bardan, and Sylwia Szostak. 2019. "Festive Television in the Socialist World: From Media Events to Media Holidays". figshare. https://hdl.handle.net/2134/21998. 
This is a pre-print manuscript, accepted for publication on 09 June 2016, due to appear in the Journal of Popular Television in Volume 5 (2017), Issue 1.

\title{
Festive Television in the Socialist World: From Media Events to Media Holidays ${ }^{1}$
}

Simon Huxtable, Sabina Mihelj, Alice Bardan, Sylwia Szostak (Loughborough University)

\begin{abstract}
This article focuses on the ways in which socialist television sought to create a sense of extraordinary temporality out of the ordinary through its coverage of historical commorations, national days, and secular and religious festivities. To do so, it develops the notion of 'media holidays', which draws on Dayan and Katz's seminal notion of media events, and the work of other scholars of media ritual to show the ways in which socialist television created extraordinary temporalities through scheduling. Drawing on schedule analysis and archival documents, the article compares the cases of television in East Germany, the Soviet Union, and Yugoslavia. It examines a number of different kinds of media holiday on socialist television, and shows how different kinds of holidays and commemoration were marked with different kinds of programming in which entertainment played an important role.
\end{abstract}

Keywords: Television, Media Events, Media Rituals, Commemoration, Scheduling, Socialism, Communism

\footnotetext{
${ }^{1}$ This research was funded by the Leverhulme Trust, RPG-2013-025. We would like to thank Aleksandra Milovanović and Mila Turaljić for their help in acquiring some of the Yugoslav materials.
} 
This is a pre-print manuscript, accepted for publication on 09 June 2016, due to appear in the Journal of Popular Television in Volume 5 (2017), Issue 1.

In recent years, scholars have investigated the ways in which holidays and commemorations contribute to national identity. Studies have shown that national commemorations allow for a period of 'reflect[ion] upon the identity of the collective they belong to' (Gammelgaard and Šarič 2012: 5), but are also inherently unstable in their attempts to unify heterogeneous identities under a single banner (Geisler 2009). Research into holidays and commemorations employs a variety of approaches, but relatively few scholars focus on the relationship between media and national commemorations (but see Castelló and Castelló 2009; Šarič et al. 2012). In this article, we seek to expand on existing literature by attending to the ways in which television sought to create extraordinary time by marking festive occasions. Focusing in particular on scheduling and behind-the-scenes discussions, the article draws on research conducted during the course of the Screening Socialism project on television during state socialism, to investigate how Eastern European socialist regimes used what we call 'media holidays' to consolidate power. ${ }^{2}$

In doing so, this article will expand existing scholarship on television in Eastern Europe research which was once almost non-existent (but see Paulu 1973), but now constitutes an important sub-field of television studies (Roth-Ey 2011; Mustata 2011; Gumbert 2014; Evans 2016; Imre 2016). Working from both a historical and a media studies perspective, these scholars have enriched our understanding of state socialist television and corrected many assumptions about its workings. Based on the assumption that television is a medium of the ordinary, embedding itself in the everyday rituals of individuals and families, this article focuses on occasions when socialist television sought to transcend the quotidian by creating a

\footnotetext{
2 Screening Socialism is a three-year research project (2013-2016) that studies the role of television in socialist Eastern Europe. It uses oral history, archival documents and programme schedule analysis to investigate the role of television in everyday life, the messages it disseminated to the public, and its role in public memory of the socialist period. See http://lboro.ac.uk/screening-socialism for more details.
} 
This is a pre-print manuscript, accepted for publication on 09 June 2016, due to appear in the Journal of Popular Television in Volume 5 (2017), Issue 1.

sense of extraordinary time. It does so by focusing on socialist festivals - those occasions in the year which were marked out as somehow 'special'. These occasions ranged from calendric events like the New Year to religious events like Christmas and Easter, and commemorations of historical events.

In this way, the article seeks not only to contribute to literature on national holidays and media history, but also seeks to expand the conceptual vocabulary of the field. The concept of the 'media event', coined by Daniel Dayan and Elihu Katz (1992) to describe the 'high holidays of mass communication' (1) in which history is broadcast and routines are interrupted, has become ubiquitous within the field of media studies and beyond. In recent years, Dayan and Katz themselves, as well as several other scholars (Cottle 2006; Couldry 2003; Mihelj 2008) have debated the efficacy of the term, and suggested revisions to the concept.

With these scholars in mind, this article will argue for the importance of 'media holidays' as one of the key rituals that television can engender. Such media holidays provide an interesting point of departure for researchers for a number of reasons. They work within a different temporal economy from media events in terms of duration and in terms of their relation to 'liveness'. While media events are centred on a single event, transmitted live, media holidays are temporally more diffuse, extending over a longer period of time, and including both live and pre-recorded programming. Briefly put, both media events and media holidays depart from the routines of everyday life and are pre-planned, but they interrupt the everyday in various ways. Secondly, media holidays, to the extent that they are often connected to national holidays, have an important bearing on questions of national unity, belonging, and allegiance. Finally, media holidays play an important part in the broadcast year, making the study of such 
This is a pre-print manuscript, accepted for publication on 09 June 2016, due to appear in the Journal of Popular Television in Volume 5 (2017), Issue 1.

holidays of interest to scholars within television studies, and particularly the readers of this special issue on seasonal TV.

The analysis that follows is in four sections. The next section situates our article within existing literature on media events and national commemoration. Section two then discusses the article's choice of case studies, introduces our sources, and introduces a typology of four types of media holiday. Sections three and four then analyse each of these four types by drawing on empirical data. A conclusion sums up the contribution made by the article to existing theories of media ritual, while also suggesting possibilities for further research.

\section{From Media Events to Media Holidays}

This article aims to fill a gap in the literature concerning the temporality of television. Although much literature has focused on the nature of temporality in individual TV productions and on the patterns of routine temporality at work in scheduling, less attention has been devoted to the question of how television creates a sense of extraordinary time. Yet television does not simply encompass the routine (Scannell 1996), but also periodically serves to transfigure everyday time into something extraordinary (see Mihelj and Huxtable 2016).

However, intense debate, much of it influenced by sociological and anthropological approaches, has surrounded the notion of the 'media event'. The canonical iteration of this discussion comes from Daniel Dayan and Elihu Katz who, in their seminal 1992 text Media Events, elaborated a theory of the power of modern mass media in relation to ritual events. For Dayan and Katz 'media events' aim both to construct and, they imply, actively foster social integration. In this sense, media events serve to 'integrate societies in a collective heartbeat and evoke a renewal of loyalty to the society and its legitimate authority' (9). In 
This is a pre-print manuscript, accepted for publication on 09 June 2016, due to appear in the Journal of Popular Television in Volume 5 (2017), Issue 1.

other words, the role of 'media' in the 'media event' is not just as a broadcaster of events, but the performer of a symbolic alchemy which reaffirms society’s 'sacred centre'.

Subsequent authors, while recognising the importance of Dayan and Katz's findings, have challenged some of their assertions. Both Nick Couldry (2003) and Simon Cottle (2006) have argued for the importance of 'ritual' in considering the media event. Couldry, pursuing an anthropological approach, has argued that the authors' 'neo-Durkheimian' approach blinded them to the fact that society's 'sacred centre' is a construction. Couldry's reading of the media event foregrounds the symbolic and political contestation at play in any media event, and criticises the 'implicitly conservative' assumptions at the heart of the theory of media events. Cottle, by contrast, is critical of the anthropological approach to media, and instead seeks to unite under the umbrella of the 'mediatized ritual' diverse theoretical approaches to describing 'exceptional' events which 'serve to sustain and/or mobilize collective sentiments and solidarities on the basis of symbolization and a subjunctive orientation to what should or ought to be' (415).

While Cottle and Couldry differ in terms of methods, their injunction to focus on ritual over event offers a useful conceptual extension to Dayan and Katz's rather narrow focus on the live broadcasting of already-planned events (which the authors themselves have begun to move away from; see Dayan 2010). Apart from building on this shift from events to rituals, this article also draws on a particularly relevant discussion of the relationship between media and holidays developed by Friedrich Krotz (2010), which uses a Bourdiesian approach to argue that national holidays are mediated instances infused with symbolic politics to the extent that they are occasions in which a government makes 'an investment of symbolic and financial capital in order to reach specific goals' (102). While Krotz's analysis focuses on post- 
This is a pre-print manuscript, accepted for publication on 09 June 2016, due to appear in the Journal of Popular Television in Volume 5 (2017), Issue 1.

unification Germany, the connection he makes between media events and power have obvious salience for this article’s examination of media holidays during state socialism.

An important corollary of the notion of 'media ritual' is the role of television in producing what in this article we call the 'media holiday' - that is, occasions connected to major public holidays where schedules depart from their usual timings, and programmes take on a festive colouring in a bid to facilitate public celebration and commemoration. There is a relatively narrow literature on so-called 'festive viewing’ (e.g. Rothenbuhler 1988), but such literature, tending as it does to focus on sporting events, does not cover the full variety of such holidays. In relation to seasonal television, scholars have also paid attention to television at Christmas (e.g. Brabazon 2008), but this body of work focuses more on individual programming than on an analysis of television and its connection with temporality and extraordinary time. In this article, by contrast, we seek to show how a sense of festivity was produced through practices of scheduling.

\section{Case Studies, Sources and A Typology of Media Holidays}

\subsection{Socialist television?}

This article focuses on television during the period of state socialism to make wider points about media holidays. This raises the question: why socialism? One is tempted to answer: well, why not? Within media studies literature, there has long been a tendency to develop theories based on case studies from Western Europe and North America. Comparative attempts to map out the contours of various media systems have often omitted Eastern Europe from their purview (e.g. Hallin and Mancini 2004), though there have been attempts to redress this balance (Sparks 1998; Hallin and Mancini 2011; Downey and Mihelj 2012). Perhaps, 
This is a pre-print manuscript, accepted for publication on 09 June 2016, due to appear in the Journal of Popular Television in Volume 5 (2017), Issue 1.

then, there is something refreshing about 'provincialising' (Chakrabarty 2000) Western

Europe and thus reversing the usual balance of centre and periphery in media studies by presenting new concepts based on examples from socialist television.

That is not to say that one can speak of 'socialist television' as a monolithic entity. This article draws on examples from three countries: the GDR, the USSR, and Yugoslavia, which have been chosen because of their differences rather than their similarities. Of particular importance for this article are differences in political structures, which can be approached in two ways. A first area of difference concerns these countries' relationship to the nation-state model. Both the USSR and Yugoslavia possessed a federal structure in which the constituent republics played an important role, while the GDR, though painting itself as the 'true' Germany, was in reality only one half of a divided nation. As we will see, the presence of differing national frameworks of memory and identity affected the way socialist broadcasters in federalised nations sought to create a unified national memory.

Television during socialism was funded and closely supervised by national governments and industry professionals were expected to conform to the priorities set by the Party. There existed a range of structures, ranging from pre-broadcast censorship and verification of scripts to post-broadcast oversight by Party and professional bodies, which ensured that, as far as possible, television broadcast the Party line. However, industry professionals were granted a degree of freedom with respect to how they interpreted these instructions. Yet this margin of freedom varied from country to country, which again illustrates the heterogeneity of socialist television. The governments of the USSR and GDR, despite a process of liberalisation beginning in the mid-1950s, maintained rather rigid controls over their TV infrastructure, while in Yugoslavia, uniquely, the fact that advertising offered an alternative source of 
This is a pre-print manuscript, accepted for publication on 09 June 2016, due to appear in the Journal of Popular Television in Volume 5 (2017), Issue 1.

revenue allowed TV professionals greater freedoms than elsewhere (Robinson 1977).

However, reference to Yugoslavia’s historical trajectory reminds us that these countries' political paths were not static. After protests in Yugoslavia in the early 1970s, there were a number of sackings of TV personnel, and oversight of production was tightened up. Similar processes took place in the Soviet Union in the 1970s, but restrictions were loosened significantly after the accession to power of Mikhail Gorbachev in 1985. The GDR, too, became more conservative in the mid 1970s, but it resisted the changes introduced by Gorbachev in the late 1980s. In other words, just as there are many versions of socialist television across countries and regions, there are also different 'socialist televisions' over time, as research is beginning to reveal.

\subsection{Sources and Methods}

As Karen Gammelgaard and Ljiljana Šarič (2012) have argued, festivals are produced both by the discourses that constitute them and the discourses that surround them. While existing studies mostly focus on discursive production through analysis of the language used to discuss national holidays (see the contributions in Šarič et al. 2012), this study examines the topic by analysing how such festivals were produced by creative and professional elites in collaboration with Party elites, who devoted much attention to producing a festive atmosphere for viewers, with discussions of scheduling beginning many months before the actual event.

The article employs two main sources for analysing this interaction. Firstly, it relies on an analysis of television schedules to see how a sense of festivity was produced, both through the choice of programmes, their difference from ‘ordinary’ programmes, and the prominence of certain kinds of programmes in prime time. Secondly, the article looks (where available) at archive sources which demonstrate both internal professional discussions and directions from 
This is a pre-print manuscript, accepted for publication on 09 June 2016, due to appear in the Journal of Popular Television in Volume 5 (2017), Issue 1.

the Party. Through these documents, it is possible to demonstrate both the importance that Party elites placed upon media holidays, and the motivations behind professionals' scheduling choices. Thus, this article largely focuses on the top-down processes through which media holidays were inaugurated on socialist television, though in the conclusion we briefly suggest how focusing on audiences might offer an interesting perspective for future research.

\subsection{A Typology of (Media) Holidays}

In the analysis that follows, we will outline various forms of national holidays, based on the diverse identities, memories and allegiances they summoned, with a view to investigating whether these different kinds of holiday led to divergent kinds of television commemoration. We identify four main kinds of holiday, which rely for their power on references to (1) history; (2) identities; (3) religion; and (4) the passing of calendrical time. Of course, the boundaries between these are not absolute: ‘identity’, especially national identity, is intertwined with all four types of holiday, while references to history may also appear in identity-linked holidays. Nevertheless, the typology is useful for showing the ideological foundations of socialist holidays. The table below illustrates these forms of holiday in the three countries in our sample.

\section{FIGURE 1: Major Public Holidays in Socialist Countries}


This is a pre-print manuscript, accepted for publication on 09 June 2016, due to appear in the Journal of Popular Television in Volume 5 (2017), Issue 1.

\begin{tabular}{|c|c|c|c|c|}
\hline Date & Occasion & USSR & GDR & Yugoslav \\
\hline 1 January & New Year's Day & $\mathrm{x}$ & $\mathrm{x}$ & $\mathrm{xx}$ \\
\hline 8 March & Women’s Day & $\mathrm{x}$ & & \\
\hline Varies & Good Friday & & $\mathrm{x}$ & \\
\hline 12 April & $\begin{array}{l}\text { Day of the } \\
\text { Cosmonaut }\end{array}$ & $\mathrm{X}$ & & \\
\hline 1 May & $\begin{array}{l}\text { Day of Worker } \\
\text { Solidarity }\end{array}$ & $\mathrm{xx}$ & $\mathrm{x}$ & $\mathrm{xx}$ \\
\hline 9 May & Victory Day (USSR) & $\mathrm{x}$ & & \\
\hline Varies & Whit Monday & & $\mathrm{x}$ & \\
\hline 4 July & Day of Fighters & & & $\mathrm{x}$ \\
\hline 7 October & National Day & & $\mathrm{x}$ & \\
\hline $\begin{array}{l}7-8 \\
\text { November }\end{array}$ & $\begin{array}{l}\text { Anniversary of } \\
\text { October Revolution }\end{array}$ & $\mathrm{xx}$ & & \\
\hline $\begin{array}{l}29 \\
\text { November }\end{array}$ & National Day & & & $\mathrm{xx}$ \\
\hline 5 December & Constitution Day & $\mathrm{X}$ & & \\
\hline 25 December & Christmas Day & & $\mathrm{X}$ & \\
\hline 26 December & St. Stephen’s Day & & $\mathrm{X}$ & \\
\hline
\end{tabular}

\footnotetext{
${ }^{3}$ The Yugoslavian calendar contains a number of nationally-specific holidays which were only observed in the respective republics. These were a mixture of civic and, to a lesser extent, religious holidays.
} 
This is a pre-print manuscript, accepted for publication on 09 June 2016, due to appear in the Journal of Popular Television in Volume 5 (2017), Issue 1.

$\mathrm{xx}=$ Two-day holiday

\begin{tabular}{|l|l|l|}
\hline & Calendar-specific & \multirow{2}{*}{ Religious/calendar } \\
\hline & Religion-specific & \\
\hline & Identity-specific & \\
\hline & History-specific & \\
\hline
\end{tabular}

The first two forms of holiday can be considered as civic holidays, and are analysed in the next section:

Holidays based on historical commemoration are predominantly civic occasions which mark national history. Often these commemorations of historic events were turned into national days or 'days of liberation', but could also be newly coined to celebrate recent achievements, as was the case with the Soviet Union's 'Day of the Cosmonaut', celebrating Yuri Gagarin's space flight in 1961. Identity-based holidays ally themselves to specific forms of identity or allegiance. Within this category we can include holidays like International Women’s Day, which was a national holiday in the Soviet Union, and in particular May Day, which was a celebration of International Worker's Day.

In section four we examine holidays connected to certain forms of temporality, whether religious or calendrical. For obvious reasons religious holidays held an uncomfortable place in socialist societies, which saw it as their role to counter religious 'superstition'. However, as we will see, Christian holidays, such as Christmas, Easter, and Whitsun were all celebrated. Calendrical holidays, by contrast, are secular celebrations of the passing of time. On a 
This is a pre-print manuscript, accepted for publication on 09 June 2016, due to appear in the Journal of Popular Television in Volume 5 (2017), Issue 1.

personal level they are marked by birthdays, but on a national level by the commemoration of the New Year.

\section{Civic Commemorations}

\subsection{National Holidays}

As Figure 1 shows, a large proportion of national holidays during socialism was based on historical events. These festivals commemorated a wide range of past events, but on the whole can be divided into festivals that celebrated the establishment of socialism (which overlapped with questions of national 'liberation'), and those which were connected to World War II (which was celebrated in both the USSR and Yugoslavia but not in East Germany where, for obvious reasons, wartime experiences were difficult to integrate into a 'usable past' [Maier 1998]). However, the timing of Yugoslavia's 'Day of Fighters' on 4 July reflected that country’s origins in the Partisan movement, rather than Soviet liberation, and thus showed how commemorative occasions could celebrate different forms of historical memory. On occasion national days were connected to specific media events, as was the case with the parade commemorating the anniversary of the Russian Revolution in the USSR, or the military parade taking place every five years in Yugoslavia, but more often there was no specific occasion (and hence no live 'media event') to which these media holidays were tied.

For broadcasters, what was of paramount importance was for such holidays to contribute to the building of national identity through consciousness of a particular past. For example, a 1980 policy document in Yugoslavia stated that television’s task during national holidays should be to 'contribute to the strengthening the awareness of our workers' movement and the continuity of the revolution, to the affirmation of the Marxist approach to the national 
This is a pre-print manuscript, accepted for publication on 09 June 2016, due to appear in the Journal of Popular Television in Volume 5 (2017), Issue 1.

question, to the critical questioning of cultural and other traditions, and to the education of young generations in the spirit of the most progressive examples from our history' (HDA 1980).

In the Soviet Union, television broadcasting was organised to mirror the country’s political set-up. A national channel (Central Television) broadcast from Moscow, but there were also television stations representing the USSR's other fourteen republics, as well as local TV channels in the country's larger cities. However, because of the national presence of a centralised 'First Channel', commemoration of the revolution were broadcast across the country, while national studios carried their own programming on the same topic. Although Central Television would broadcast features on national-level festivals (e.g. anniversaries concerning Ukraine or Georgia), these were never accorded the same status as Soviet-wide festivals. In this way, Soviet Central Television was able to put forward a picture of a unified, Sovietised nation - albeit one dominated by Russia and the Russian language.

In Yugoslavia, by contrast, there was no national channel, but rather a number of republiclevel and provincial or regional broadcasters. As with other major holidays, all six major TV centres were involved, and each produced special festive programmes for the Day of the Republic, largely based on national traditions, but contributing to an image of pan-Yugoslav unity. These programmes would be broadcast not just within the republics that produced them, but also exchanged with other republic-level broadcasters (though this form of programme exchange was more prominent in republics that shared a common Serbo-Croatian language). For example, in 1975, TV Belgrade broadcast a portrait of a poet known for engaging with revolutionary themes in his work (The Sun is Watching Over You/Sunce te čuva, 1975), while TV Skopje broadcast a show called How Does My Homeland Grow?/ 
This is a pre-print manuscript, accepted for publication on 09 June 2016, due to appear in the Journal of Popular Television in Volume 5 (2017), Issue 1.

Kako raste domovina, 1975, consisting of recitals and songs by Macedonian children

responding to the invitation to describe the growth of their country, and TV Zagreb introduced a new television series The Bonfires of Kapela/Kapelski kresovi (1975), which focused on the story of a group of youth from Croatia joining the anti-fascist liberation struggle at the start of World War Two. This kind of patchwork of programmes produced in different republics was characteristic of Yugoslav festive television, and served to embody the 'unity in diversity' of the federation.

FIGURE 2: TV Belgrade (1) schedule, Saturday 30 November 1975 (Day of the Republic) ${ }^{4}$

\section{9:30 News}

9:40 Music: Wind orchestra concert

10:10 Culture: The Sun is Watching Over You - festive programme

10:40 Children: How Does my Homeland Grow? (Skopje)

11:10 Reportage: Victory (Sarajevo)

12:10 Warning (Zagreb) - no detail

13:00 Knowledge - Property: programme for farmers, with elements of entertainment, education and information

15:00 Sport: Volleyball

16:40 News

17:00 Sport: Handball (tournament dedicated to the Day of the Republic)

18:15 Music: Children are Singing - Festive children’s concert

\footnotetext{
4 For reasons of space we do not provide translations of programme titles for this and subsequent schedules except for films.
} 
This is a pre-print manuscript, accepted for publication on 09 June 2016, due to appear in the Journal of Popular Television in Volume 5 (2017), Issue 1.

\section{9:15 Cartoon}

19:20 A Screen for Every Home - no detail

\section{9:30 News}

20:00 Mini-Series: Bonfires of Kapela

21:20 Word by Word - Festive 'party’ (including a talk show and piano music)

\section{2:20 News}

22:40 Music: Partisan songs

The case of the 'Bonfires of Kapela' illustrates the fact that the public could not be motivated by high-minded sentiments alone. Television schedules on national days tended to mix journalism with cultural programming and drama with entertainment to ensure the highest possible ratings. Fictional mini-series like ‘Bonfires’ or Liberation/Osvobozhdenie (1968-72), broadcast during the Victory Day celebrations in the USSR, combined historical themes with dramatic narratives, perhaps creating a more effective vehicle for the regime’s reading of history than more direct assertions of historical reality. This trend was not limited to drama: in the Soviet Union, the immensely popular variety show Little Blue Flame/Goluboi ogonek (1962-1985), which was broadcast on all major public holidays, was (as our oral history interviews showed) extremely popular with viewers for its combination of music, comedy skits, and dance, which would be focused on the relevant occasion. For example, on Victory Day (8 May), there might be marching bands and prominent veterans interspersed with comedy skits. Such programmes show that TV producers recognised that viewers could not be won over by noble sentiments alone, but also needed diversion.

\subsection{Identity-led Holidays: 1 May}


This is a pre-print manuscript, accepted for publication on 09 June 2016, due to appear in the Journal of Popular Television in Volume 5 (2017), Issue 1.

While the holidays discussed in the previous section relied on historical occasions for their significance, other commemorations relied on specific forms of identity, whether of gender, of class, or, as we will see, of international socialist identities. One example is provided by International Women's Day on 8 March, which remains an important part of the commemorative calendar in post-Soviet countries, and which was celebrated on socialist television with a range of programming specifically aimed at women, or geared towards celebrating their achievements.

However, the most important event of this kind was the May Day holiday. 1 May differed from history-led occasions largely because of its centring around a key media event: a parade which took place in every town and city, large or small. It can therefore be compared with certain kinds of media event in Western countries, such as Trooping the Colour or the Queen’s Speech in the United Kingdom. Yet in ideologically-saturated socialist nations (and especially the USSR), the atmosphere of the event permeated the whole day, making it more similar to the 4 July festivities in the United States or Bastille Day in France. In some ways, the May Day parade provides one of the clearest examples of a television festivity: it enlisted the full power of socialist media, which played an integral part in the planning and in the actual proceedings; the parades were trailed for many days or even weeks beforehand in the media, and they emphasised tradition and ceremony.

Identity-led festivities were bound to national and transnational allegiances. Festivals on 8 March and 1 May celebrated the contribution of individuals to the construction of communism in their own nations, but also spoke of an international fraternity of women or workers ('Workers of the world unite!'). Articles published in the run-up to the events emphasised 'proletarian internationalism', and the programmes broadcast sought to do so, too. 
This is a pre-print manuscript, accepted for publication on 09 June 2016, due to appear in the Journal of Popular Television in Volume 5 (2017), Issue 1.

In the GDR, for instance, the five-hour(!) broadcast of the 1 May parade from Berlin, Halle, Neubrandenburg and Frankfurt-am-Oder also contained link-ups with the parade in Moscow, Warsaw, Prague, Budapest, Bucharest and Sofia. In general, television coverage on such occasions aimed to show national achievements alongside visions of international harmony. In the USSR, such broadcasts sang the praises of socialist internationalism, and its live broadcast of the parade in 1975 spoke of the Soviet Union's assistance from the “fraternal countries of the socialist world" to fight for a "durable peace and international friendship" and to "relieve international tensions". 5

But despite such messages of international harmony, coverage reflected underlying geopolitical imbalances. Soviet internationalism was coloured by a sense that brotherhood was the Soviet Union's gift to the rest of the world for which socialist states should, it was implied, be grateful. The unbalanced relationship of centre to periphery was particularly central in the GDR where the country’s debt to Moscow was illustrated by the broadcasting of shows like Moscow Celebrates the First of May/Moskau feiert den 1. Mai in Russian in 1975 or the live broadcasting of Moscow's celebrations alongside programmes like Unforgotten! At the Memorial for the Heroes of the Soviet Army/Unvergessen! An Gedenkstätten für die Helden der Sowjetarmee in 1980. It thus provided a nationally particular internationalist narrative, which suggested that the 'fraternal peoples' of Eastern Europe were the children of the socialist family. To this extent, we could argue that the 1 May holiday did not simply present a positive vision of proletarian identities, but also provided proof of the prevailing geopolitical order - one in which the Soviet Union stood at the centre as a benevolent father to its socialist children.

\footnotetext{
5 Festive Demonstration / Prazdnichnaia demonstratsiia https://www.youtube.com/watch?v=Ny nbD9U2j4.
} 
This is a pre-print manuscript, accepted for publication on 09 June 2016, due to appear in the Journal of Popular Television in Volume 5 (2017), Issue 1.

Soviet schedules display similarities between May 1 and national days. Only in the USSR was there a real sense of 1 May being an extraordinary occasion, where the atmosphere of festivity pervaded the whole day through celebratory concerts, sporting occasions, premieres of films and documentaries, news programmes, or iconic variety broadcasts like the aforementioned Little Blue Flame. Schedules offer more evidence to support the notion put forward in the previous section that TV professionals had realised the importance of entertainment as a way of tempting viewers to watch less alluring news and documentary programming. On May Day 1975, schedulers split the two-and-a-half hour broadcast of Little Blue Flame into two parts, which allowed for the scheduling of reportage in the prime time 9pm slot, which seems to have been an attempt to ensure maximum viewing figures for the most ideologically saturated programme in the schedule: a reportage on the 1 May parades across the world, replacing the usual news programme.

In other countries, May Day was less saturated with festive programming than on national days. East German schedules largely returned to normal after the broadcast of the parade in the morning, and the May Day holiday was far from dominant in Yugoslavia, too. Yugoslavia’s reluctance to participate fully in the May Day festivities perhaps rests on its strained relationship with Moscow. There, the implicit socialist internationalism of May Day sat uncomfortably with the independent geopolitical stance taken by Tito after 1948, when Yugoslavia split from the Soviet-led communist movement. As a result, the changing relationship between May Day and Victory Day can be seen as reflecting that country’s shifting geopolitical position. In fact, the country’s main military parade, originally organised for May Day, was moved in 1965 to 9 May (Victory Day), and for financial reasons took place only every five years. The decision to move to 9 May is in itself interesting, and suggests a move away from Moscow-dominated socialist internationalism towards an 
This is a pre-print manuscript, accepted for publication on 09 June 2016, due to appear in the Journal of Popular Television in Volume 5 (2017), Issue 1.

emphasis on a specifically Yugoslav national identity. The presentation of Yugoslavia’s entanglements with the rest of the world depended on Yugoslavia's geopolitical stance at the time: sometimes Yugoslavia was shown as a key participant in the Non-aligned Movement; ${ }^{6}$ at other points, Yugoslav festivities would be linked with festivities in the rest of socialist Eastern Europe and in the West alike. Thus, Yugoslav festive television also offered a nationally particular internationalist narrative, only this time not linked to the socialist family of nations, but to the 'family' of non-aligned nations or the more generic global 'family' of nations.

As we have seen, the two forms of civic festivals outlined in this section were premised on different kinds of memories and identities. While national commemorative days were based on the presence of distinct national identities and sought to inculcate a sense of patriotism through reference to the heroic past and national culture, identity-based commemorations sought to express allegiances transcending national borders. However, commemorations reflected underlying historical and geopolitical tensions, either through the side-lining of references to World War II in the GDR, or through reference to alternative international solidarities in Yugoslavia. A sense of the 'extraordinary' was transmitted both through the saturation of everyday programming with festive content, but also through canny use of scheduling to ensure that viewers were exposed to the desired messages, as well as by mixing entertainment with historical and ideological content to present the Party line in a compelling fashion. By combining ideological messages with entertainment in this way, TV professionals could communicate with audiences more effectively.

\footnotetext{
${ }^{6}$ The Non-Aligned Movement, inaugurated in 1961, was a group of nations which aligned themselves neither to the Soviet nor the United States during the Cold War.
} 
This is a pre-print manuscript, accepted for publication on 09 June 2016, due to appear in the Journal of Popular Television in Volume 5 (2017), Issue 1.

\section{Religious and Calendar-based Holidays}

Socialist regimes officially regarded religion as dangerous superstition that threatened the new scientific order. Many adopted atheist policies, which strained relations with organized religious structures. The USSR and Yugoslavia both sought to relegate Christmas to the sidelines in their respective countries’ commemorative calendars - for example by replacing references to Father Christmas with 'Grandfather Frost' (Ded moroz in Russian or Deda Mraz in Serbo-Croatian) (see Dushechkina 2003; Gradišnik 2004). The degree to which religion was tolerated was also visible in the amount of official recognition afforded to religious ceremonies. By contrast, in the GDR, despite a residual antipathy towards religion, there was a sense in which religion was part of national identity; religious figures like Martin Luther and Thomas Müntzer were celebrated as national heroes (see Roy 2000; Fleischauer 2010) and religious holidays including Easter, Whitsun, and Christmas were officially recognised. Thus, in countries where religious belief was stigmatized, there emerged a gap between private and public identities, with religious holidays celebrated only among family and friends. ${ }^{7}$

A comparison of television schedules for the USSR and the GDR illustrates the difference between these two approaches to religious holidays: while in the USSR, with its strongly held policy of official atheism, there was no mention of religious holidays in public discourse, in

\footnotetext{
${ }^{7}$ This tension between private observance and public dismissal of Christmas festivities served as the basis of an episode of the widely watched Yugoslavian serial Our Little Town/Naše malo misto, 1970-1971), in which Party officials try to deflect attention from the Midnight Mass service by organising a concert of patriotic and revolutionary songs. Because of the battle between the two, neither event succeeds.
} 
This is a pre-print manuscript, accepted for publication on 09 June 2016, due to appear in the Journal of Popular Television in Volume 5 (2017), Issue 1.

East Germany the centre of gravity for the entire TV year was the Christmas and New Year period, with the accent on the former. The most-watched television programme related to the festive period was the variety show Between Breakfast and Roast Goose/Zwischen Frühstück und Gansebraten (1957-1991) broadcast on Christmas morning, while many of the most country’s most prominent serial dramas premiered in the Christmas period. Religious programming, though far from prominent, was not entirely erased either: in 1980, on Christmas Eve (a date when German families tend to congregate), the second channel broadcast Monteverdi’s 1610 Vespers, followed by a midnight broadcast of Bach’s organ works from St. Kilian’s Church in Bad Lautsick, with a further Bach performance on Christmas Day. While both of these programmes could be considered to be cultural, their scheduling allowed them to play a religious role.

Because of the GDR's proximity to West Germany, and the fact that broadcasts from the Federal Republic were easily accessible to the vast majority of the population, the battle for viewership became a fight for political loyalty (see Dittmar 2010) as well as for national identity. Christmas became a Cold War battlefield, with both East and West laying claim to being the heirs to the 'true' Christmas, and thus the ‘true’ Germany (Perry 2001). Since Christmas and New Year were times when East German viewers were almost guaranteed to be watching television, the festive season was fraught with anxieties. The East German state broadcaster began work on its Christmas schedules several months in advance (for example, in 1974-1975, discussions began in May) to ensure the largest possible audience, and there were intense discussions about programmes considered to be of a low standard (SAPMOBArch 1974a, b). However, festive television in the GDR was a balancing act between the need to ensure viewer satisfaction and the desire to maintain ideological orthodoxy. Officials expressed a desire to balance entertainment with current affairs programming that reflected 
This is a pre-print manuscript, accepted for publication on 09 June 2016, due to appear in the Journal of Popular Television in Volume 5 (2017), Issue 1.

the current Party line, and were eager to ensure that the quest for entertainment did not contradict the Party's geopolitical line (which they did, for example, by replacing British imported programming with shows from the USSR [SAPMO-BArch 1974a]).

FIGURE 3: Schedules in GDR and BRD, Christmas Day 1966

\begin{tabular}{|c|c|}
\hline GDR & BRD (ARD) \\
\hline 08.50 Medical Notes & 10.00 News \\
\hline 09.00 Current Affairs: Viewpoint & 10.05 Music: Viennese Choirboys sing \\
\hline 09.35 Languages: English for You & Christmas Songs \\
\hline 10.00 Children's programming & 10.25 Religious: The Arrival (Events from \\
\hline 11.00 Between Breakfast and Roast Goose & Bethlehem) \\
\hline (Christmas-based variety and Chat) & 11.30 Religious: On the World's Streets \\
\hline 12.55 News & "Pictorial meditation on Christ" \\
\hline 13.30 Sport: Dreams, Feats and Triumphs & 12.00 News \\
\hline (Round-up) & 14.00 Christmas Speech of the Chancellor \\
\hline 15.00 Film: Uncle Tom's Cabin & 14.15 Children: James's Animals \\
\hline 17.15 Drama: In Sixth Heaven & 14.45 History: The Lion of Saint Mark \\
\hline 17.45 News & 15.30 Film: The Glenn Miller Story (1954) \\
\hline 17.50 Lottery: 6 of 49 & 17.25 Billy Smart's Circus \\
\hline 18.00 Current Affairs: Foreign & 18.25 Biopic: Wolfgang Amadeus Mozart \\
\hline Correspondent's Report & 19.10 Sport: Weekend Sport \\
\hline 18.45 Children's Programming & 19.50 Lottery Numbers \\
\hline 19.10 Notes on Science & 20.05 Theatre: The Two Gentlemen of \\
\hline 19.40 Lottery: Lucky Numbers & Verona \\
\hline
\end{tabular}


This is a pre-print manuscript, accepted for publication on 09 June 2016, due to appear in the Journal of Popular Television in Volume 5 (2017), Issue 1.

\begin{tabular}{|l|l|}
\hline 19.45 News & 21.35 Variety: Gerhard Winkler Has The \\
20.00 Variety: Music and Fun! & Honour ... \\
Diamond/Corinne und der Diamant (1964) & \\
22.50 News & \\
22.55 Culture: Grace, Jumps, Elegance & \\
(Ice dance finale) & \\
\hline
\end{tabular}

Aside from the muting of religious content, was there anything particularly socialist about the festive schedules? A side-by-side analysis of the outputs of East German and West German (ARD) schedules suggests not. Clearly, the distinguishing characteristic of ARD's schedule is its religious programming, which dominates the morning schedule. Yet, aside from the broadcast of the US film The Glenn Miller Story (1954), one would be hard pressed to tell the difference between the two: both featured a festive drawing of the lottery numbers; both prime time schedules were built around a major variety show; both gave prominence to imported films from the West. In other words, television was understood and was operating as a popular medium focused on attracting the widest possible audience across the East-West border.

FIGURE 4: Central Television USSR (1), 31 December 1975

9.00 News

9.10 Morning Gymnastics

9.30 Cartoons

10.05 Winter Holiday (Unknown) 
This is a pre-print manuscript, accepted for publication on 09 June 2016, due to appear in the Journal of Popular Television in Volume 5 (2017), Issue 1.

10.20 Children's Film: Masha and Vitia's New Year Adventures/Novogodnie prikliucheniia Mashi i Viti (1975)

11.30 Documentary: Creativity of the World's Peoples

12.00 Children: Real Children

13.30 Theatre for children

15.00 Documentary: Comrade Woman

15.35 Ballet

16.55 Culture: Folk Creativity

17.40 Concert: Magic Snowmen

18.00 News

18.15 Documentary: On the Eve of the 25th Congress of the CPSU.

19.15 Lottery: Sportlotto

19.30 Film: Ivan Vasil'evich Changes Profession/Ivan Vasil'evich meniaet professiiu (1973)

21.00 News

21.30 Puppet Theatre

23.00 Circus: Circus Lights

23.40 Documentary: My Country

23.50 Happy New Year, Comrades!

0.05 Variety: Little Blue Flame

3.05 New Year's Concert

While Christmas was an ordinary day in the USSR and Yugoslavia, the schedule around New Year's Eve focused on entertainment in all three countries. Listings magazines promised viewers a day full of humour and light-hearted music, with a particular focus on programmes for children. There was little reference to socialist identities in listings magazines which 
This is a pre-print manuscript, accepted for publication on 09 June 2016, due to appear in the Journal of Popular Television in Volume 5 (2017), Issue 1.

instead favoured references to entertainment (e.g. Milenković 1972), though Soviet schedulers usually tried to throw in more ideological programmes, such as the enticing-sounding documentary On the Eve of the 25th Congress of the Communist Party. Nevertheless, broadcasts for New Year's Eve bequeathed some of the most popular and best-remembered programmes of the socialist era. In the GDR, a 'party'-type show broadcast hits from East and West, while in both the Soviet Union and Yugoslavia, the New Year's Eve TV schedules revolved around a central variety show consisting of comic sketches, dance and music performances specifically designed for the show by popular actors and musicians.

Programmes ended in the early hours of the morning, as opposed to the normal closedown time of around midnight.

In the Soviet Union, the variety programme Little Blue Flame, which was broadcast on all festive occasions, reached its most elaborate iteration on New Year's Eve. Planned and recorded several months in advance, the New Year edition was an extravaganza lasting several hours, featuring comedy, celebrities, chat and cabaret, which (as our interviews showed) became an obligatory part of the New Year's ritual. Some of the material broadcast poked very mild fun at social problems within the country, while shows broadcast on New Year's Eve in the GDR and Yugoslavia contained similar satirical material. Such programmes provided a safety valve for letting off steam in a similar fashion to satirical magazines like Krokodil in the USSR.

Similar mild satire could be glimpsed a day later, on New Year’s Day 1976, when Soviet Central Television broadcast the premiere of the late El'dar Riazanov's TV movie Irony of Fate/Ironiia sud'by (1975). This romantic comedy depicts a relationship which flowers when the Muscovite lead character, Zhenia, having passed out drunk the night before, wakes up the 
This is a pre-print manuscript, accepted for publication on 09 June 2016, due to appear in the Journal of Popular Television in Volume 5 (2017), Issue 1.

next day in Leningrad due to a mix-up. However, because of the uniformity of Soviet architecture and street naming, he does not realise he is in a different city. When he tries his key in the door of his apartment on 'Constructors' Street' in Leningrad it works and, still in a drunken stupor, he gets into bed. When the apartment owner, Nadia, returns home, her fiancé leaves, suspecting her of having an affair, and slowly but surely Nadia and Zhenia begin a romance. The film's comedy is made possible by the presence of distinctive Soviet 'common places', at which the film pokes affectionate fun. Today, the film is considered a classic, and the film is still watched by huge audiences when it is repeated during the New Year holiday.

If we compare TV schedules at Christmas and on New Year's Eve to those broadcast on civic holidays, the difference between the two types of media holiday is clear. To the extent that calendrical and religious holidays did not refer to distinctly socialist or national identities, these holidays instead celebrated a sense of unity based on a shared way of life, and in doing so created distinct media rituals. These rituals were neither based on religious identities (except to a limited extent in the GDR) nor on specifically socialist ones, but rather on the simple fact of living in a socialist nation. On these occasions, the focus was on providing entertainment to the masses: a gift to the toiling worker which bore out Leonid Brezhnev’s reported remarks that 'The Soviet person has the right to relax in front of the television set after a day’s work’ (Roth-Ey 2011: 201).

\section{Conclusion}

This article has outlined how various holidays were covered on television in the GDR, the USSR and Yugoslavia, focusing in particular on practices of scheduling. In doing so, the article has put forward the idea of the 'media holiday': a mediated instance where festivity is produced by the scheduling of festive-themed broadcasting and special programmes. Whereas 
This is a pre-print manuscript, accepted for publication on 09 June 2016, due to appear in the Journal of Popular Television in Volume 5 (2017), Issue 1.

existing research has tied festive television narrowly to specific media events, this article has suggested a wider variety of distinct ways in which television's scheduling contributes to the process of structuring a sense of extraordinary time, and thereby also to fostering different kinds of identities, ranging from national and transnational to gender, religious and class identities. The article has shown particularly clearly the differences between civic and religious/calendrical media holidays: while both relied on entertainment programmes, this was especially pronounced in the case of the latter.

Making comparisons between East and West is difficult because of a lack of research into the relationship between television and holidays in general. The article has suggested both similarities and differences between media festivals during state socialism, and those existing in the West. Most explicitly, a comparison of Christmas schedules across divided Germany suggested that despite ideological differences, there were similarities in the use of entertainment to attract viewers. However, the case of Christmas also reveals obvious differences between East and West: because of state-mandated atheist policies, television ignored the festival in Yugoslavia and the USSR, while it was only tangentially covered in the GDR. Because of this, more weight was placed upon New Year's Eve and New Year's Day as a source of rituals. The second key difference concerns socialist television's focus on national and international commemorations, which were more comprehensive than those of most Western countries outside the United States (though more research into different non-socialist cases would be needed to confirm these findings). Even here, however, we found significant differences across the three nations in our sample, both in terms of the types of national identities and historical memories commemorated, but also in the degree of coverage afforded to these occasions. Thus, the article suggests that different iterations of socialist television, 
This is a pre-print manuscript, accepted for publication on 09 June 2016, due to appear in the Journal of Popular Television in Volume 5 (2017), Issue 1.

and different iterations of media holidays, were premised on heterogeneous state, political, cultural and religious traditions.

Because of a lack of space, this article has only delivered a top-down perspective on media holidays. Interviews conducted as part of the Screening Socialism project as well as audience research conducted during state socialism suggest that television played an important part in constituting distinct media rituals. As one Ukrainian participant in the project said of New Year's Eve: 'we didn’t conceive of it that we could miss these festivals. Just like the Olivier salad on the table, these programmes on television and watching them were an integral part of the life of the Soviet person' (Ukraine-11 Woman, born 1952). But such research also suggests that media festivals had more resonance during calendrical and religious dates, rather than civic holidays. We might therefore argue that socialist television was most successful when it was least socialist, and least successful when it attempted to extoll its own virtues. Of course, more research would be needed to test this line of argument, but connecting top-down and bottom-up perspectives offers a promising line for future scholarship.

By focusing on media holidays, this article has emphasised the importance of the comparative examination of the cultures that socialist television engendered. Existing research on media systems tends to focus on how political, economic and legal systems can account for different forms of mass communication. While the case of state socialism highlights the importance of political and legal considerations in accounting for media diversity, this article has suggested that future research into mass television must also account for the role of television as an everyday actor with a role in organizing the patterns of everyday life. In doing so, future research may seek to move from researching media systems to media cultures as a way of 
This is a pre-print manuscript, accepted for publication on 09 June 2016, due to appear in the Journal of Popular Television in Volume 5 (2017), Issue 1.

investigating the cultures of television, of which these socialist media holidays are a part, that contribute to the distinct role of television in structuring our sense of space and time. 
This is a pre-print manuscript, accepted for publication on 09 June 2016, due to appear in the Journal of Popular Television in Volume 5 (2017), Issue 1.

\section{BIBLIOGRAPHY}

Brabazon, T. (2008), 'Christmas and the Media’ in S. Whiteley (ed.), Christmas, Ideology, and Popular Culture, Edinburgh: Edinburgh University Press, pp. 149-163.

Castelló, E. and Castello. R. (2009), ‘One Country, Three National Days: Nations, Citizenship and Media Discourses in Valencia’ in D. McCrone and G. McPherson (eds), National Days: Constructing and Mobilising National Identity, Basingstoke: MacMillan, pp. 181-196.

Chakrabarty, D. (2000), Provincializing Europe: Postcolonial Thought and Historical Difference, Princeton, NJ: Princeton University Press.

Cottle, S. (2006), 'Mediatized Rituals: Beyond Manufacturing Consent’, Media, Culture and Society, 28: 3, pp. 411-432.

Couldry, N. (2003), Media Rituals: A Critical Approach, London: Routledge.

Dayan, D. and Katz, E. (1992), Media Events: The Live Broadcasting of History, Cambridge, MA: Harvard University Press.

Dayan, D. (2010), ‘Beyond Media Events: Disenchantment, Derailment, Disruption’ in N. Couldry, A. Hepp and F. Krotz (eds), Media Events in a Global Age, London: Routledge, pp.23-31. 
This is a pre-print manuscript, accepted for publication on 09 June 2016, due to appear in the Journal of Popular Television in Volume 5 (2017), Issue 1.

Dittmar, C. (2010), Feindliches Fernsehen: Das DDR-Fernsehen und seine Strategien im Umgang mit dem westdeutschen Fernsehen [Enemy Television: GDR Television and its Strategies to Deal With West German Television], Bielefeld: Transcript.

Downey, J. and Mihelj, S. (eds) (2012), Central and Eastern European Media in Comparative Perspective: Politics, Economy Culture, Aldershot: Ashgate.

Dushechkina, E. (2003), ‘Ded Moroz i Snegurochka’ [Grandfather Frost and the Snow Maiden], Otechestvennye zapisk, 1 http://magazines.russ.ru/oz/2003/1/2003_01_31.html. Accessed 21 June 2015.

Evans, C. (2016), Between Truth and Time: A History of Soviet Central Television, New Haven, NJ: Yale University Press.

Fleischauer, A (2010), Die Enkel fechten’s besser aus. Thomas Müntzer und die Frühbürgerliche Revolution - Geschichtspolitik und Erinnerungskultur in der DDR [The Grandchildren Work Things Out Better: Thomas Müntzer and the Early Bourgeois Revolution - The Politics of History and Memory Culture in the GDR], Münster: Ascheundorff.

Gammelgaard, K. and Šarić, L. (2013), 'Discursive Construction of National Holidays in West and South Slavic Countries After the Fall of Communism’ in L. Šarić, K. Gammelgaard and K. Hauge (eds), Transforming National Holidays: Identity discourse in the West and South Slavic Countries, 1985-2010, Amsterdam: John Benjamins, pp. 5-31. 
This is a pre-print manuscript, accepted for publication on 09 June 2016, due to appear in the Journal of Popular Television in Volume 5 (2017), Issue 1.

Geisler, M. (2009), ‘The Calendar Conundrum: National Days as Unstable Signifiers’ in D.

McCrone and G. McPherson, National Days: Constructing and Mobilising National Identity, Basingstoke: Macmillan, pp. 10-25.

Gumbert, H. (2014), Envisioning Socialism: Television and the Cold War in the German Democratic Republic, Ann Arbor, MI: University of Michigan Press.

Gradišnik, I. (2015), ‘A Festive Bricolage: The Holiday Calendar in Slovenia over the Last Century', Folklore: Electronic Journal of Folklore, 60, pp.38-39.

Hallin, D. and Mancini, P. (2004), Comparing Media Systems: Three Models of Media and Politics, Cambridge: Cambridge University Press.

Hallin, D. and Mancini, P. (eds) (2012), Comparing Media Systems Beyond the Western World, Cambridge: Cambridge University Press.

HDA (1980), 'Smernice za programsku politiku jugoslovenskih TV stanica za 1981. godinu’ [Guidelines for Yugoslav TV's Political Programming for 1981], Committee for Television of the Yugoslav Radio-television, Croatian State Archive, 1980 - 1228-SSRNH-1980-d5601ProgramskeOrientacijeJRT.

Imre, A. (2016), TV Socialism. Durham, NC: Duke University Press. 
This is a pre-print manuscript, accepted for publication on 09 June 2016, due to appear in the Journal of Popular Television in Volume 5 (2017), Issue 1.

Krotz, F. (2010), 'Creating a National Holiday: Media Events, Symbolic Capital and Symbolic Power' in N. Couldry, A. Hepp and F. Krotz (eds), Media Events in a Global Age, London: Routledge, pp. 95-108.

Maier, C. (1998), The Unmasterable Past: History, Holocaust, and German National Identity, Cambridge, MA: Harvard University Press.

Mihelj, S. (2008), ‘National Media Events’, European Journal of Cultural Studies 11: 4: 471488.

Mustata, D. (2011), 'The Power of Television: Including the Historicizing of the Live Romanian Revolution’, Unpublished PhD Dissertation, University of Utrecht.

Paulu, B. (1973), Radio and Television Broadcasting in Eastern Europe, Minnesota: Minnesota University Press.

Perry J. (2001), 'The Private Life of the Nation: Christmas and the Invention of Modern Germany’, Unpublished PhD Thesis, University of Illinois at Urbana-Champaign.

Robinson, G. (1977), Tito's Maverick Media: the Politics of Mass Communications in Yugoslavia, Urbana, IL: University of Illinois Press.

Rothenbuhler, E. (1988), 'The Living Room Celebrations of the Olympic Games', Journal of Communication, 38: 4, pp.61-81. 
This is a pre-print manuscript, accepted for publication on 09 June 2016, due to appear in the Journal of Popular Television in Volume 5 (2017), Issue 1.

Roth-Ey, K. (2011), Moscow Prime Time: How the Soviet Union Built the Media Empire That Lost the Cultural Cold War, Ithaca, NY: Cornell University Press.

Roy, M. (2000), Luther in der DDR. Zum Wandel des Lutherbildes in der DDR-

Geschichtsschreibung [Luther in the GDR. On the Changing Image of Luther in GDR History Writing], Bochum: Winkler.

Šarić, L. (2013), 'Croatia in Search of a National Day: Front-page Presentations of NationalDay Celebrations, 1988-2005’ in L. Šarić, K. Gammelgaard and K. Hauge (eds), Transforming National Holidays: Identity discourse in the West and South Slavic Countries, 1985-2010, Amsterdam: John Benjamins, pp. 125-148.

SAPMO-BArch (1974a), 'Zum neuen Entwurf des Jahresendprogramms’ [On the new draft schedule for the end of the year] , 15 October, DY 30 / vorl. SED 14358/1.

SAPMO-BArch (1974b), 'Vorschläge für die Gestaltung des Hauptabendprogramms des Fernsehens der DDR über die Weihnachtsfeiertage’ [Suggestion for the arrangement of the main evening schedule of GDR Television over the Christmas holidays], 14 November, SAPMO-BArch DY 30 / vorl. SED 14358/1.

Scannell, P. (1996), Radio, Television and Modern Life, London: Blackwell.

Sparks, C. (1998), Communism, Capitalism and the Media in Eastern Europe, London: Sage. 
This is a pre-print manuscript, accepted for publication on 09 June 2016, due to appear in the Journal of Popular Television in Volume 5 (2017), Issue 1.

Milenković, N. (1972), ‘Mjuzikl začinjen humorom’ (A Musical Spiced with Humour), TV

Novosti, 29 December 1972, p.12-13

\section{TELEVISION PROGRAMMES}

Between Breakfast and Roast Goose/Zwischen Frühstück und Gansebraten (1957-1991, DDR-F)

The Bonfires of Kapela/Kapelski kresovi (1975, TV Zagreb)

Festive Demonstration/Prazdnichnaia demonstratsiia (1975, Central Television Moscow)

The Glenn Miller Story (1954, Universal)

How Does My Homeland Grow?/ Kako raste domovina (1975, TV Skopje)

Liberation/Osvobozhdenie (1968-72, Mosfil'm (Russia)/Alava-fil'm (Yugoslavia)/PRF-ZF (Poland)/DEFA (GDR)/Dino De Laurentiis (Italy))

Little Blue Flame/Goluboi ogonek (1962-1985, Central Television Moscow)

Moscow Celebrates the First of May/Moskau feiert den 1. Mai (1975, Intervision)

Unforgotten! At the Memorial for the Heroes of the Soviet Army/Unvergessen! An Gedenkstätten für die Helden der Sowjetarmee (1980, Intervision)

Our Little Town/Naše malo misto (1970-1971, RTV Zagreb)

The Sun is Watching Over You/Sunce te čuva (1975, TV Belgrade)

\section{CONTRIBUTOR DETAILS}

Simon Huxtable is a research associate on the Screening Socialism project at Loughborough University. He specialises on the history of media during state socialism, with a particular focus on the USSR. His articles have appeared in journals such as Cahiers du monde russe and VIEW Journal of European Television History and Culture, as well as the recent collection Rethinking Stagnation in the Brezhnev Era: Ideology and Exchange (2016). He is currently writing a monograph on the press and the public sphere in the Soviet Union after Stalin and co-writing a monograph on socialist television with Sabina Mihelj. 
This is a pre-print manuscript, accepted for publication on 09 June 2016, due to appear in the Journal of Popular Television in Volume 5 (2017), Issue 1.

Contact details: School of Social Sciences, Loughborough University, Epinal Way,

Loughborough, Leicestershire LE11 3TU

Email: s.huxtable@lboro.ac.uk

Sabina Mihelj is Professor of Media and Cultural Analysis at Loughborough University, the

UK. Her main areas of expertise include mass communication and cultural identity, comparative media research, television studies and the cultural Cold War, and she is currently leading a major project investigating television, everyday life and memory in communist and post-communist Eastern Europe. Her publications include Media Nations: Communicating Belonging and Exclusion in the Modern World (Palgrave, 2013) and Central and Eastern European Media in Comparative Perspective (with John Downey, Ashgate, 2012).

Email: S.Mihelj@lboro.ac.uk

Alice Bardan holds a Ph.D from the University of Southern California, Los Angeles, where she now teaches in the Marshall School’s Center for Management Communication. She has worked as a Research Associate on the Leverhulme-funded project "Screening Socialism", focusing primarily on the history of Romanian television. Her articles on Eastern European media have appeared in several edited collections, including Entertaining the New Europe: Popular Television in Socialist and Post-Socialist Europe; News Parody and Political Satire Across the Globe; Transnational Feminism in Film and Media; The Blackwell Companion to East European Cinema; Branding Post-Communist Nations; and in the refereed journals New Cinemas; Flow; and Popular Communication.

Email: bardan@usc.edu 
This is a pre-print manuscript, accepted for publication on 09 June 2016, due to appear in the Journal of Popular Television in Volume 5 (2017), Issue 1.

Sylwia Szostak completed her Ph.D. in the University of Nottingham's Department of

Culture, Film and Media. It examines the impact of international media flows on Polish

television in the post-Soviet era, with particular attention to the influence of American fiction

television. Sylwia has published essays in VIEW Journal of European Television History and

Culture and in the edited anthology Popular Television in Eastern Europe During and Since

Socialism (Routledge, 2013). She currently works in the Polish TV industry. 